\title{
Is endoscopic submucosal dissection still limited to few tertiary centers in the West? Results from a national survey in Brazil
}

\author{
Vitor N ARANTES ${ }^{1,2}$, Maria das Graças Pimenta SANNA ${ }^{1}$, Jairo Silva ALVES ${ }^{1}$, \\ Daniela Medeiros MILHOMEM-CARDOSO ${ }^{3}$ and Fauze MALUF-FILHO ${ }^{4}$
}

Received: 16 July 2020

KEY-SUMMARY - ESD is a popular technique in Japan and other Asian countries and supposedly is still limited to tertiary centers in the West. This National survey conducted in Brazil, the largest country of Latin-America reveals that ESD currently is practiced in the community settings and not only in academic or tertiary settings. The study also reveals interesting features about the experience, clinical practice and training amongst Brazilian ESD operators.

ABSTRACT - Background - Endoscopic submucosal dissection (ESD) enables en bloc excision of superficial neoplasms. Although ESD is widely practiced in Eastern countries like Japan, South Korea and China, its use in the West is supposed to be still limited to few tertiary centers. Objective - This study aimed to investigate the clinical practice of ESD in Brazil by means of an electronic questionnaire elaborated by the Brazilian Society of Digestive Endoscopy (SOBED). Methods - In October 2019, 3512 endoscopist members of SOBED were invited to respond to an electronic survey containing 40 questions divided into four topics: operator profile; clinical experience with ESD; adverse events and training. Informed consent was requested to all participants. The investigators reviewed all responses and considered valid if more than $50 \%$ of the questions were answered and additional information, when requested, was provided. Results - A total of 155 (4.4\%) qualified responses entered the study. ESD has been practiced in 22 of 26 Federation States and majority of respondents (32.2\%) have 10 to 20 years of practice. ESD has been performed more frequently in private hospitals (101 individuals, $66.9 \%)$ and private ambulatory centers (41 individuals, $27.1 \%$ ). ESD was performed mainly in the stomach (72\%), followed by the rectum ( $57 \%$ ) and $80 \%$ of the individuals reported less than 25 operations. Twenty-four (15.4\%) individuals reported perforation and $4(2.5 \%)$ of them reported postoperative deaths. Approximately a quarter of responders denied hands-on training in models or visit to training centers. Conclusion - ESD appears to be practiced throughout the country, not only in tertiary or academic institutions and mainly in private practice. Most operators received limited training and still are at the beginning of their learning curve. The reported adverse events and mortality rates appear to be higher than Eastern reports.

HEADINGS - Endoscopic mucosal resection. Physicians' practice patterns. Clinical practice. Surveys and questionnaires.

\section{INTRODUCTION}

Endoscopic submucosal dissection (ESD) has been developed in Japan and enables en bloc excision of superficial neoplasms utilizing dedicated knives ${ }^{(1-4)}$. ESD is an organ-sparing operation that has lower morbidity and mortality in comparison to surgery and has the potential to provide better quality of life ${ }^{(5)}$. From the oncological perspective it has been suggested that ESD techniques are equally effective in comparison to surgical treatment for superficial neoplasms with negligible risk of lymph node metastasis ${ }^{(2,3)}$. Moreover, ESD application has been expanded on a worldwide basis and is progressively attracting attention and acceptance ${ }^{(6-9)}$.

Although ESD is widely practiced in Eastern countries like Japan, South Korea and China, its use in the West is supposed to be still limited to few tertiary centers. Many reports from Western countries have presented similar results in terms of clinical outcome in comparison to Eastern publications, with less number of patients $^{(9-14)}$. Western countries have recently conducted surveys regarding ESD practice in order to assess the evolution of ESD experience, training and outcomes ${ }^{(6,15-17)}$

This study aimed to investigate the current clinical practice of ESD in Brazil by means of an electronic questionnaire sent to all members of the Brazilian Society of Digestive Endoscopy (SOBED), the largest endoscopy association in Latin America with more than 3500 members.

\section{METHODS}

In October 2019, 3512 endoscopist members of SOBED included in our mailing list were invited to respond to an electronic survey containing 40 questions, elaborated by SOBED Scientific Commission. An Internet link was established to provide access to the online questionnaire using Survey Monkey ${ }^{\circledR}$ software. The questionnaire included 40 questions divided into four topics: 1- operator

Declared conflict of interest of all authors: none

Disclosure of funding: no funding received

None to be declared related to this manuscript. No funding source for this study.

Universidade Federal de Minas Gerais, Faculdade de Medicina, Instituto Alfa de Gastroenterologia, Unidade de Endoscopia, Belo Horizonte, MG, Brasil. ${ }^{2}$ Hospital Mater Dei Contorno, Unidade de Endoscopia, Belo Horizonte, MG. Brasil. ${ }^{3}$ Hospital Geral de Goiânial (HGG), Unidade de Endoscopia, Goiania, GO, Brasil. ${ }^{4}$ Instituto do Câncer do Estado de São Paulo (ICESP), Unidade de Endoscopia, SP, Brasil.

Corresponding author: Vitor N. Arantes, MD, MSc, PhD. E-mail: arantesvitor@ufmg.br 
identification and background; 2- clinical experience with ESD in humans; 3- occurrence of adverse events and 4- training process. Informed consent was requested to all individuals for utilization of submitted answers in this study. All endoscopists were encouraged to fulfill the survey as close as possible to their reality and all responses were traceable. The investigators reviewed all responses and considered them valid if more than $50 \%$ of the questions were addressed and additional information, when requested, were provided by the endoscopist.

Prior to national enrollment, a pilot questionnaire was distributed to members of Scientific Committee to complete and provide feedback. It enabled the main investigator (Arantes V) to test the software for data analysis and comprehension of the questionnaire. On the basis of the feedback received, the questionnaire was further refined ahead of sending it to all Society members. The questionnaire was sent on three separate occasions, to increase the response rate. In addition, advertising messages were sent in all digital media platforms of SOBED inviting ESD practitioners to respond the online survey.

\section{Data analysis}

Data were collected and extracted with graphs and tables from the software database and prepared for statistical analysis that was basically descriptive due to the characteristics of the survey. Variables were summarized using absolute and relative frequencies, weighted means and medians. Percentages were calculated based on the total number of participants and the number of responses to each individual question.

\section{Ethical considerations}

The authors declare that the study consisted on an analysis of questionnaires responses sent by SOBED members. Only respondents that agreed to participate in the study and provided consent were included in the research. There were no experiments of any kind performed on animals or humans, as well as no contact with patients, and it was conducted according to the Declaration of Helsinki reviewed in 2008. This study was approved by SOBED Directory Board and Ethics Committee in September 18th 2019 and complied with all norms for scientific research, including the confidentiality of data of the respondents.

\section{RESULTS}

A total of $444(12.6 \%)$ individuals accessed the questionnaire and $376(10.7 \%)$ responses were received. After reviewing process, 221 responses were excluded (eight individuals denied consent, 203 presented incomplete responses and 10 did not provide requested additional information). In total $155(4.4 \%)$ responses were considered valid and entered the study (FIGURE 1).

ESD has been performed in 22 of 26 Federation States, although around $50 \%$ of the ESD operators are concentrated in Southeast region, which is the most populated in the country (FIGURE 2). TABLE 1 outlines the responder's profile. A total of $50(32.2 \%)$ respondents reported 10 to 20 years of endoscopy practice and 65 $(41.9 \%)$ participants aged between 35 and 45 years. In terms of residency background $99(63.8 \%)$ respondents received surgical training and $40(25.8 \%)$ individuals were clinical gastroenterologists. ESD procedures have been performed mainly in private hospitals (101 individuals, 66.9\%) and private ambulatory centers (41 individuals, $27.1 \%$ ). ESD has been practiced in public and university hospitals by $40(26.4 \%)$ and $37(24.5 \%)$ respondents, respectively.

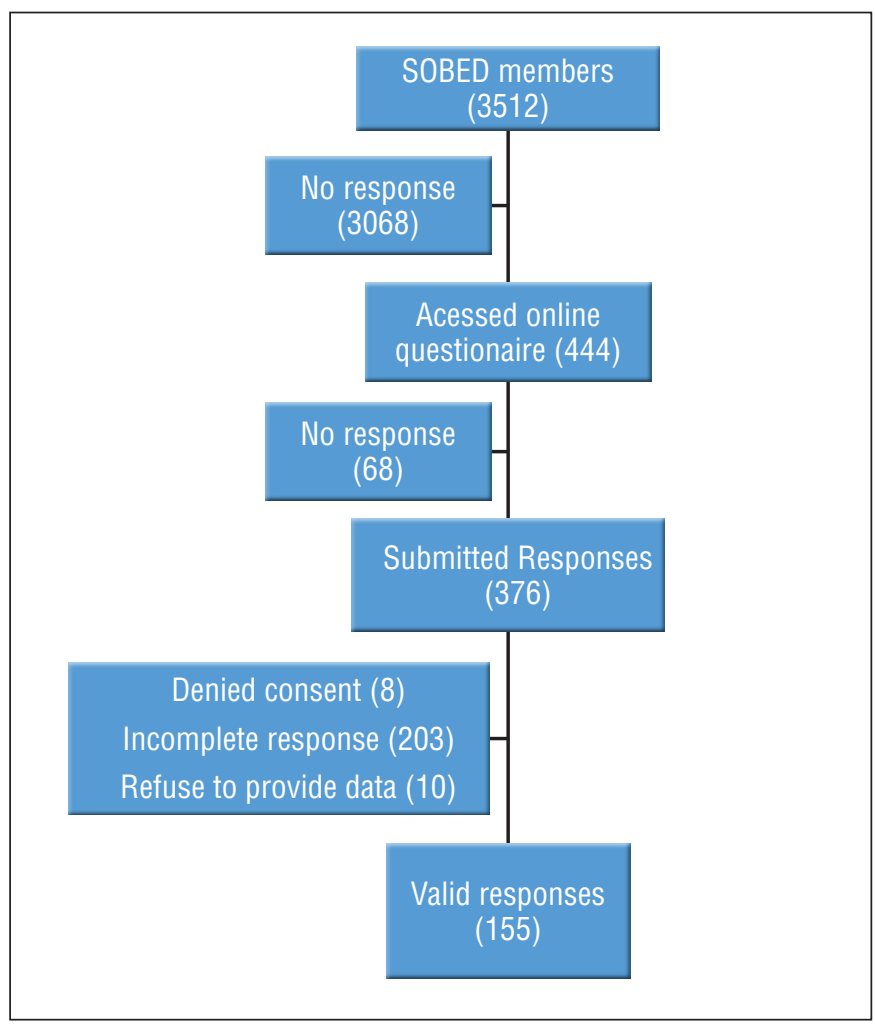

FIGURE 1. Fluxogram of the study design.

TABLE 1. Personal characteristics of the endoscopist.

\begin{tabular}{|c|c|c|c|}
\hline & & $\mathbf{N}$ & $(\%)$ \\
\hline \multirow{8}{*}{ Age (years) } & $<30$ & 1 & 1.2 \\
\hline & $30-35$ & 21 & 13.5 \\
\hline & $35-40$ & 31 & 20 \\
\hline & $40-45$ & 34 & 21.9 \\
\hline & $45-50$ & 22 & 14.2 \\
\hline & $50-55$ & 14 & 9 \\
\hline & $55-60$ & 15 & 9.6 \\
\hline & $>60$ & 16 & 10.3 \\
\hline \multirow{4}{*}{$\begin{array}{l}\text { Residency } \\
\text { background }\end{array}$} & Gastroenterology & 40 & 25.8 \\
\hline & Surgery & 99 & 63.8 \\
\hline & Colorectal Surgery & 9 & 5.8 \\
\hline & Internal Medicine & 7 & 4.5 \\
\hline \multirow{5}{*}{$\begin{array}{l}\text { Endoscopic } \\
\text { experience } \\
\text { (years) }\end{array}$} & $<5$ & 19 & 12.2 \\
\hline & $5-10$ & 35 & 22.5 \\
\hline & $10-20$ & 50 & 32.2 \\
\hline & $20-30$ & 33 & 21.2 \\
\hline & $>30$ & 18 & 11.6 \\
\hline
\end{tabular}




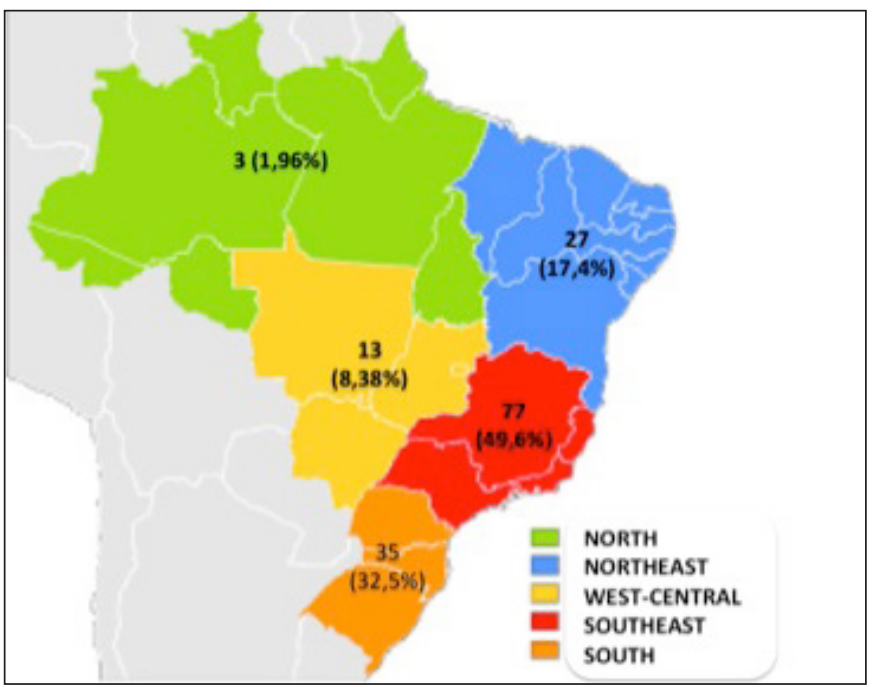

FIGURE 2. Distribution of the respondents according to Brazil's regions.

TABLE 2 describes the personal experience of the participants. ESD was carried out mainly in the stomach $(72 \%)$, followed by rectum $(57 \%)$ and colon $(44 \%)$. The majority of participants described an initial ESD experience and have not overcome yet the learning curve of 50 procedures: $98(63.2 \%)$ individuals reported less than 10 procedures, 27 reported between 10 and $25(17.4 \%)$ and 10 operators described between 25 and $50(6.5 \%)$ cases. Only three operators described more extensive experience over 150 $(1.9 \%)$ procedures.

TABLE 2. Endoscopic submucosal dissection clinical experience reported by the participants.

\begin{tabular}{lccc}
\hline & & N & $\%$ \\
\hline & Stomach & 109 & 72.1 \\
& Esophagus & 41 & 27.2 \\
Personal experience & Duodenum & 12 & 7.9 \\
according to organ & Colon & 67 & 44.3 \\
& Rectal & 86 & 56.9 \\
& Hypopharynx & 2 & 1.3 \\
& & & \\
Personal ESD experience & $<10$ & 98 & 63.2 \\
(number of cases) & $10-25$ & 27 & 17.4 \\
& $25-50$ & 10 & 6.4 \\
& $50-75$ & 11 & 7.1 \\
& $75-100$ & 2 & 1.3 \\
& $100-150$ & 0 & 0 \\
& $150-200$ & 2 & 1.3 \\
& $>200$ & 1 & 0.65 \\
\hline
\end{tabular}

ESD: endoscopic submucosal dissection.

TABLE 3 summarizes the clinical practice of ESD. A wide range of dedicated knives was used and most endoscopists reported that ESD procedures were performed under anesthesiologistsedation or general anesthesia ( $45.1 \%$ and $43.8 \%$, respectively). $\mathrm{CO}_{2}$ insufflation was utilized by $92(59.3 \%)$ individuals and only 39 $(25 \%)$ respondents used endoscopes with virtual chromoendoscopy and magnification. Approximately half of responders (49.7\%) reported usage of high-frequency electrosurgical generators and distal attachment caps were utilized by $124(80 \%)$ endoscopists. Regarding the solutions for submucosal injection, saline solution $(36.7 \%)$, mannitol $(29 \%)$ and starch $(27 \%)$ were the most popular substances utilized. Sodium hyaluronate use was reported by only $5.1 \%$ of the respondents. In total $92(59.3 \%)$ endoscopists hospitalized patients for ESD, whereas near $40 \%$ of them (63 respondents) performed ESD in day-hospital or as an outpatient procedure.

TABLE 3. Endoscopic submucosal dissection technical details according to the respondents.

\begin{tabular}{|c|c|c|c|}
\hline & & $\mathbf{N}$ & $\%$ \\
\hline \multirow{7}{*}{$\begin{array}{l}\text { ESD knife of } \\
\text { preference* }\end{array}$} & IT-knife & 35 & 22.5 \\
\hline & Flush-knife & 57 & 36.7 \\
\hline & Hook-knife & 7 & 4.5 \\
\hline & Dual-knife & 5 & 3.2 \\
\hline & Hybrid-knife & 14 & 9 \\
\hline & Needle-knife & 28 & 18 \\
\hline & Other knife & 9 & 5.8 \\
\hline \multirow{5}{*}{$\begin{array}{l}\text { Solution for } \\
\text { submucosal } \\
\text { injection* }\end{array}$} & Saline & 57 & 36.7 \\
\hline & Sodium hyaluronate & 8 & 5.2 \\
\hline & Mannitol & 45 & 29.1 \\
\hline & Starch & 42 & 27.1 \\
\hline & Other & 3 & 1.9 \\
\hline \multirow{2}{*}{$\begin{array}{l}\text { Use of } \mathrm{CO}_{2} \\
\text { insufflator }\end{array}$} & Yes & 92 & 59.4 \\
\hline & No & 63 & 40.6 \\
\hline \multirow{3}{*}{$\begin{array}{l}\text { Availability of } \\
\text { endoscopes* }\end{array}$} & $\begin{array}{l}\text { Standard white-light } \\
\text { endoscopy }\end{array}$ & 55 & 35.5 \\
\hline & Virtual chromoendoscopy & 61 & 39.3 \\
\hline & $\begin{array}{l}\text { Virtual chromoendoscopy } \\
\text { plus magnification }\end{array}$ & 39 & 25.2 \\
\hline \multirow{3}{*}{$\begin{array}{l}\text { High-frequency } \\
\text { electrosurgical } \\
\text { generators with } \\
\text { EndoCut }{ }^{\circledR} \text { mode }\end{array}$} & Yes & 77 & 49.7 \\
\hline & No & 78 & 50.3 \\
\hline & Yes & 124 & 80 \\
\hline \multirow[t]{2}{*}{ Use of cap } & No & 16 & 10 \\
\hline & Selected cases & 15 & 10 \\
\hline \multirow{4}{*}{$\begin{array}{l}\text { Usual type of } \\
\text { sedation* }\end{array}$} & General anesthesia & 68 & 43.4 \\
\hline & Sedation with anesthesiologist & 70 & 45.1 \\
\hline & $\begin{array}{c}\text { Sedation without } \\
\text { anesthesiologist }\end{array}$ & 10 & 6.5 \\
\hline & Sedation with nurse assistance & 7 & 4.5 \\
\hline \multirow{3}{*}{$\begin{array}{l}\text { Hospital } \\
\text { admission } \\
\text { routine* }\end{array}$} & Hospitalization & 92 & 59.3 \\
\hline & Day-hospital & 32 & 20.7 \\
\hline & Outpatient & 31 & 20 \\
\hline
\end{tabular}

* More than one answer was allowed; ESD: endoscopic submucosal dissection. 
TABLE 4 demonstrates adverse events and mortality. Intraoperative perforation was experienced by $55(40.7 \%)$ respondents and delayed perforation was reported by $24(17.6 \%)$ respondents. Looking into this information in a more detailed manner, $12(8.8 \%)$ endoscopists reported personal perforation rate between 5 and $10 \%$, three endoscopists $(2.2 \%)$ between 10 and $20 \%$ and one respondent reported a perforation rate over $20 \%$. The most affected organs for perforation were the stomach $(23.5 \%)$, and the colon $(19.1 \%)$. A total of $97(79.2 \%)$ respondents were able to manage perforation endoscopically, while $27(22.3 \%)$ endoscopists referred patients to surgery. Massive bleeding needing urgent surgery was reported by $13(9.5 \%)$ respondents. Moreover, $18(13.2 \%)$ endoscopists reported a requirement for blood transfusion after ESD. Overall $4(2.9 \%)$ responders reported patient's death related to ESD.

TABLE 4. Adverse events related to endoscopic submucosal dissection reported by the respondents.

\begin{tabular}{lccc}
\hline & & N & $\%$ \\
\hline Intraoperative perforation & Yes & 55 & 40.7 \\
& No & 80 & 59.3 \\
Delayed perforation & No & 24 & 17.7 \\
& & 112 & 82.3 \\
& $<2 \%$ & 61 & 44.8 \\
Personal perforation rate & 2-5\% & 14 & 10.3 \\
& 5-10\% & 12 & 8.8 \\
& $10-20 \%$ & 3 & 2.2 \\
& $>20 \%$ & 1 & 0.7 \\
& Not informed & 45 & 33.1 \\
& & & \\
Perforation by organ* & Esophagus & 10 & 7.3 \\
& Stomach & 32 & 23.5 \\
& Duodenum & 0 & 0 \\
& Colon & 26 & 19.1 \\
& Rectum & 22 & 16.1 \\
& No perforation & 73 & 53.7 \\
& & & \\
& Yes & 4 & 2.9 \\
& No & 132 & 97.1 \\
\hline
\end{tabular}

* More than one answer was allowed.

TABLE 5 reveals ESD training process. The majority of respondents visited referral centers, mostly within Brazil (71 respondents), followed by Japan (19 respondents), however almost one quarter of the responders $(23.2 \%)$ never visited ESD centers. The period of training usually was shorter than 1 month (58.9\%) and only $14(11.9 \%)$ respondents reported more than 6 months of training. Of note, $26(22.2 \%)$ respondents denied hands-on training in animal models prior to ESD practice. In contrast, 74 $(63.2 \%)$ individuals had the opportunity to work as assistant of procedures performed by a more experienced endoscopist and 24 $(20 \%)$ respondents received an expert at their institution to provide training. Interestingly, $53(45.3 \%)$ respondents started their first procedures without supervision. Only $16(13.6 \%)$ endoscopist published papers related to ESD in scientific journals.
TABLE 5. Endoscopic submucosal dissection learning process informed by the responders.

\begin{tabular}{|c|c|c|c|}
\hline & & $\mathbf{N}$ & $\%$ \\
\hline \multirow{7}{*}{$\begin{array}{l}\text { Visit to ESD referral } \\
\text { centers* }\end{array}$} & No & 27 & 25.2 \\
\hline & Japan & 19 & 16.3 \\
\hline & Asia/Oceania & 2 & 1.7 \\
\hline & Europe & 12 & 10.3 \\
\hline & North America & 13 & 11.2 \\
\hline & Brazil & 71 & 61.2 \\
\hline & Latin America & 5 & 4.3 \\
\hline \multirow{7}{*}{$\begin{array}{l}\text { Duration of visit to ESD } \\
\text { Center* }(\mathrm{w} \text { - weeks })\end{array}$} & $<1 \mathrm{w}$ & 45 & 38.4 \\
\hline & $1-2 \mathrm{w}$ & 13 & 11.1 \\
\hline & $2-4 \mathrm{w}$ & 11 & 9.4 \\
\hline & $4-8 \mathrm{w}$ & 8 & 6.8 \\
\hline & $12-24 \mathrm{w}$ & 8 & 6.8 \\
\hline & $>24 \mathrm{w}$ & 14 & 11.9 \\
\hline & Other & 18 & 15.3 \\
\hline \multirow{3}{*}{$\begin{array}{l}\text { Hands-on training in } \\
\text { models* }\end{array}$} & No & 26 & 22.2 \\
\hline & Ex-vivo & 36 & 30.7 \\
\hline & $\begin{array}{l}\text { Ex-vivo and alive } \\
\text { models }\end{array}$ & 55 & 47.1 \\
\hline \multirow{2}{*}{$\begin{array}{l}\text { Work as first assistant of } \\
\text { ESD procedure }\end{array}$} & Yes & 74 & 63.3 \\
\hline & No & 43 & 36.7 \\
\hline \multirow{2}{*}{$\begin{array}{l}\text { Performed first ESD cases } \\
\text { supervised by an expert }\end{array}$} & Yes & 64 & 54.7 \\
\hline & No & 53 & 45.3 \\
\hline \multirow{2}{*}{$\begin{array}{l}\text { Received foreign ESD } \\
\text { expert visit for training }\end{array}$} & Yes & 24 & 20.5 \\
\hline & No & 93 & 79.5 \\
\hline
\end{tabular}

* More than one answer was allowed; ESD: endoscopic submucosal dissection.

\section{DISCUSSION}

This survey is the first and most comprehensive picture of ESD practice in Brazil, the largest country in Latin America. A total of 155 SOBED associates ( $4.4 \%$ of all members) answered the survey, a figure that reflects the approximate number of Brazilian ESD practitioners. It is important to emphasize that only qualified questionnaire answers were admitted and we obtained complete responses in $75.4 \%$ of them. Moreover, $87.1 \%$ of the respondents were board certified as specialist in Endoscopy, meaning that they were approved in a theoretical and practical exam with curriculum vitae analysis that assessed their endoscopy skills and knowledge, granting a certificate recognized by SOBED and the Brazilian Medical Association. It is noticeable that most of the respondents were young (45 years-old or less), with 10-20 years of endoscopy experience, and surgical residency as their training background $(63.8 \%)$. Those findings could reflect the interest of younger endoscopist with surgical training in advanced procedures.

The majority of respondents $(63.2 \%)$ had performed less than 10 procedures and only three participants had more than 100 
cases. Many respondents had ESD experience in more than one organ. Such information resembles data reported in other Western surveys ${ }^{(6,12-16)}$. Those findings could be partially explained by the absence of an organized screening program for superficial neoplasia detection, resulting in a low number of cases from different organs. It is noteworthy that most procedures were performed in private hospitals or ambulatory centers. Nonetheless, high definition endoscopes with magnification, high-frequency electrosurgical generators, $\mathrm{CO}_{2}$ insufflation and distal cap were available in $25 \%$, $50 \%, 60 \%$ and $80 \%$ of the cases, respectively. In fact, ESD is a standardized technique, which requires not only a trained endoscopist but also infrastructure to carry out the procedure safely and with a high level of effectiveness. Moreover, before undertaking ESD it is very important to develop an expertise in early tumor detection, characterization and delineation, a critical aspect of the endoscopic management or superficial neoplasms that currently relies heavily on image-enhanced endoscopy tools. It would be expected that those technologies should be available to all operators. The lack of these resources apparently indicates that, in Brazil and perhaps other countries, ESD practice is growing outside main referral centers or tertiary level hospitals, indicating that community endoscopist have decided to start ESD in their own endoscopy centers despite not having access to the latest endoscopy technologies or even an ESD expert to provide guidance in the first procedures. Furthermore, for most endoscopists ESD training consisted in short term $(<1$ week) visits to Brazilian centers associated with some ex-vivo/animal model training. These aspects could partially explain the observed heterogeneity in ESD technique, exemplified by the usage of a wide range of knives and solutions for submucosal injection. This finding probably translates the personal preferences of ESD practitioners and is similar to what was reported in other Western studies ${ }^{(13-17)}$.

Around $40 \%$ of the respondents reported perforation probably reflecting their initial learning curve and the limited training. The majority of endoscopists that experienced perforation during ESD informed that their perforation rate were under $10 \%$, a parameter that is considered of importance to determine the competence level of an operator. Nevertheless, it is of concern that three operators self-reported perforation rates between 10 and $20 \%$ and one individual described perforation rate above $20 \%$. Delayed perforation rate was also quite high in the present survey $(17.4 \%)$. The mechanism of this late perforation was not clear to us. We believe that some of the cases of late perforation corresponded to immediate perforation overlooked by the endoscopist during the procedure. In addition, $22 \%$ of the respondents reported severe complications that required surgical treatment. This could reflect the limited experience of the respondents in the management of adverse events. In fact, 9.5\% of the endoscopists reported the need for surgical intervention to arrest bleeding which is unusual in large ESD series.

The first reports of ESD from Europe also showed disappointing outcomes, according to nationwide surveys conducted to assess the profile of the endoscopist performing ESD and to monitor clinical outcomes ${ }^{(13-15)}$. In France, the reported adverse events rate was $29.2 \%$ in the early days of ESD practice ${ }^{(15)}$. Some authors also found a positive effect of the learning curve lowering adverse events rate in high volume centers ${ }^{(16)}$. If we look at more recent Western surveys the accumulated experience with ESD over years has leaded to improvements in outcome. In France, a nationwide survey enrolling 14 ESD centers was organized to monitor ESD clinical outcome and adverse events rate in two different periods of time - 2008 to
2010 and 2010 to $2013^{(17)}$. The first period included 188 patients and in the second period the sample size almost doubled to 314 patients. The authors demonstrated that in the latest period the en bloc resection rate improved from $77.1 \%$ to $91.7 \%$ and the adverse event rate dropped from $29.1 \%$ to $14.1 \%$ (still over $10 \%$ ). It is of note that the $\mathrm{R} 0$ resection rate has remained unchanged around $72 \%$ (under the recommended $80 \%$ rate), indicating a need to improve tumor delineation and to increase safety margins of ESD procedure. Another European survey from 2010 reported at that time a major adverse event rate of $13 \%$ for gastric $\mathrm{ESD}^{(6)}$. Recently these authors published an updated survey further evaluating the implementation of ESD in the West ${ }^{(18)}$. A total of 58 experts agreed to participate in the investigation and reported a decrease in the adverse event rate to only $3 \%{ }^{(18)}$. Recently, a nationwide survey was conducted in Italy, with the participation of experts from 23 centers. In this selected population almost $60 \%$ of the operators reported less than 80 ESD operations and there was a wide variation in training protocols, practice settings and case volume/year ${ }^{(19)}$. ESD learning curve is considered to be relatively long. Choi et al. reported that 20 human cases is the minimal number to learn the basic principles of ESD (20). Kakushima et al. suggested that competence requires more than 30 procedures, meaning that only approximately $16.7 \%$ of Brazilian endoscopists (26 respondents) has achieved this level of ESD competence ${ }^{(20,21)}$.

In Japan ESD training has a stepwise approach: 1- learn basic principles of lesion detection and characterization and observe ESD procedures; 2- work first as assistant and start hands-on practice in models; 3- perform less difficult procedures for smaller lesions in the antrum or rectum with supervision; 4- progress to more challenging cases with tutoring; 5- self-conducted ESD operation. ESD experts from United States and Europe also have proposed a multi-step training process and minimum curriculum for ESD practice, which includes proficiency in EMR, visits to high-volume centers and hands-on training in models before starting in humans ${ }^{(8,22-24)}$. A survey conducted with ESD course participants identified several barriers to the establishment of ESD in the United States: paucity of early lesions, complexity and duration of the procedure, lack of a structured training system and costs of the equipment and devices $^{(7)}$. We feel that those barriers also played a major role in the results reported at the present survey.

This study has some limitations including the fact that it was based on personal reports and relied on the accuracy of the information provided by each participant. Nonetheless, as the responses were not anonymous, the investigators were able to check the informed data whenever needed, and a failure to provide satisfactorily additional information leaded to exclusion of the questionnaire. The relatively low qualified response rate to the survey $(4.4 \%)$ is also concerning. We envision two possible explanations. First, although ESD practice is expanding everywhere, it remains limited to a small number of dedicated therapeutic endoscopists. This assumption has also been demonstrated in a recent British survey involving practitioners of colorectal EMR and polypectomy, reporting that only $3 \%$ of the colonoscopists practice ESD in the United Kingdom $^{(25)}$. Secondly, an unknown number of operators may have not been reached by the survey either because they are not SOBED members or refused to answer the questionnaire. In addition, we did not collect any information regarding en bloc, $\mathrm{R} 0$ resection, and recurrence rates to assess the clinical outcome of the operations. Nevertheless, considering that ESD is a complex procedure that even in Japan is usually practiced by a selected number of 
trained endoscopists, we admit that the number of responses were beyond our expectations and the number of operators involved were much higher than any other survey published so far in the Western world. Actually, other national surveys invited only endoscopists from referral centers known to perform ESD or that had published about $\mathrm{it}^{(17-19)}$, and this may be the first national survey opened to all community endoscopists that were affiliated to an Endoscopy Association. Most likely this reflects that ESD has been established globally to manage superficial neoplasms and an increasing number of specialists, particularly the youngest ones and those dedicated to therapeutic procedures are eagerly interested in embarking on ESD and to offer this kind of service to their communities. Lastly, this survey has not addressed an important topic about the respondents background, training and expertise to detect and characterize early gastrointestinal tumors, a matter that is still of great importance, particularly in the Western world.

In conclusion, ESD appears to be practiced throughout Brazil, not only in tertiary or academic institutions, but also mainly in private practice. Gastric ESD leads the experience in Brazil, differently from other Western countries. Most ESD operators have received limited training in animal models, visited referral centers for less than one week and are at the beginning of their learning curve. Moreover access to latest technologies and image-enhanced endoscopy has not been universal amongst operators. The reported outcomes in terms of adverse events and mortality rates appear to be higher than Eastern reports and similar to initial studies in the early period of ESD practice in Europe. Our findings suggest that a structured curriculum for ESD training as well as the dissemination of endoscopy technologies, together with a prospective structured individual database to enable outcomes auditing, might be useful for guidance of safe ESD expansion in clinical practice.

\section{ACKNOWLEDGMENT}

The authors would like to thank the associate members of SOBED for their participation in the Survey. In addition, the authors would like to thank Mrs. Silvia Sanches and Mrs. Gisele Cardoso from SOBED administrative office for their contribution to the technical preparation and release of the online survey.

\section{Authors' contribution}

Arantes VN: conception; design; data collection and/or processing; analysis and interpretation; literature review; writing; supervision; critical review; final approval of the article. Sanna MGP, Alves JS: design; analysis and interpretation; final approval of the article. Milhomem-Cardoso DM: analysis and interpretation; literature review; writing; final approval of the article. Maluf-Filho F: design; analysis and interpretation; literature review; writing. supervision; critical review; final approval of the article.

\section{Orcid}

Vitor N Arantes: 0000-0001-8000-5298.

Maria das Graças Pimenta Sanna: 0000-0002-8327-4079.

Jairo Silva Alves: 0000-0001-6281-5967.

Daniela Medeiros Milhomem-Cardoso: 0000-0003-1742-8620. Fauze Maluf-Filho: 0000-0001-8875-420X.

Arantes VN, Sanna MGP, Alves JS, Milhomem-Cardoso DM, Maluf-Filho F. A dissecção endoscópica de submucosa ainda está limitada a poucos centros terciários no Ocidente? Resultados de uma pesquisa nacional no Brasil. Arq Gastroenterol. 2020;57(4):477-83.

RESUMO - Contexto - A dissecção endoscópica da submucosa (ESD) é uma técnica popular no Japão e em outros países asiáticos e, supostamente, ainda está limitada a centros terciários no Ocidente. Objetivo - Este estudo teve como objetivo investigar a prática clínica da ESD no Brasil por meio de um questionário eletrônico elaborado pela Sociedade Brasileira de Endoscopia Digestiva (SOBED). Métodos - Em outubro de 2019, 3512 endoscopistas membros da SOBED foram convidados a responder a uma pesquisa eletrônica contendo 40 questões divididas em quatro tópicos: perfil do operador; experiência clínica com ESD; eventos adversos e treinamento. O consentimento informado foi solicitado a todos os participantes. Os investigadores analisaram todas as respostas e consideraram válidas se mais de $50 \%$ das perguntas fossem respondidas e informações adicionais, quando solicitadas, fossem fornecidas. Resultados - Um total de 155 (4,4\%) respostas qualificadas foram incluídas no estudo. A ESD foi executada em 22 dos 26 estados da Federação e a maioria dos entrevistados (32,2\%) possuía de 10 a 20 anos de prática endoscópica. A ESD foi realizada com maior frequência em hospitais privados (101 indivíduos; 66,9\%) e clínicas ambulatoriais privadas (41 indivíduos; 27,1\%). A ESD foi realizada principalmente no estômago ( $72 \%$ ), seguido pelo reto $(57 \%)$ e $80 \%$ dos indivíduos relataram menos de 25 operações. Vinte e quatro $(15,4 \%)$ indivíduos relataram algum caso de perfuração no procedimento e $4(2,5 \%)$ deles relataram óbito pós-operatório. Aproximadamente um quarto dos respondentes negou treinamento prático em modelos ou visita a centros de treinamento. Conclusão - A ESD parece ser praticada em todo o país, não apenas em instituições terciárias ou acadêmicas e principalmente na prática privada. A maioria dos respondedores recebeu treinamento limitado e ainda está no início da curva de aprendizado. Os eventos adversos relatados e as taxas de mortalidade parecem ser maiores do que os relatos orientais.

DESCRITORES - Ressecção endoscópica de mucosa. Padrões de prática médica. Prática clínica. Inquéritos e questionários. 


\section{REFERENCES}

1. Gotoda T. Endoscopic resection of early gastric cancer. Gastric Cancer. 2007;10:1-11

2. Nonaka S, Oda I, Nakaya T, Kusano C, Suzuki H, Yoshinaga S, et al. Clinical impact of a strategy involving endoscopic submucosal dissection for early gastric cancer: determining the optimal pathway. Gastric Cancer. 2011;14:56-62.

3. Gotoda T, Yanagisawa A, Sasako M, Ono H, Nakanishi Y, Shimoda T, et al. Incidence of lymph node metastasis from early gastric cancer: estimation with a large number of cases at two large centers. Gastric Cancer. 2000;3:219-25.

4. Hosokawa K, Yoshida S. Recent advances in endoscopic mucosal resection for early gastric cancer. Gan to Kagaku Ryoho. 1998;25:476-83.

5. Libanio D, Braga V, Ferraz S, Castro R, Lage J, Rita I, et al. Prospective comparative study of endoscopic submucosal dissection and gastrectomy for early neoplastic lesions including patient's perspectives. Endoscopy. 2019;51:30-9.

6. Ribeiro Mourão F, Pimentel Nunes P, Dinis-Ribeiro M. Endoscopic submucosal dissection for gastric lesions: results of a European inquiry. Endoscopy. 2010;42:814-9.

7. Schlachterman A, Young D, Goddard A, Gotoda T, Draganov PV. Perspectives of endoscopic submucosal dissection training in the United States: a survey analysis. Endoscopy Int Open. 2018; O6: E399-E409.

8. Pimentel-Nunes P, Pioche M, Alnéniz E, Berr F, Depréz P, Ebigbo A, et al. Curriculum for endoscopic submucosal dissection training in Europe. European Society of Gastrointestinal Endoscopy (ESGE) Position Statement. Endoscopy. 2019;51:980-92.

9. Chaves DM, Moura EG, Milhomem D, Arantes VN, Yamazaki K, Maluf F, et al. Initial experience of endoscopic submucosal dissection in Brazil to treat early gastric and esophageal cancer: a multi-institutional analysis. Arq Gastroenterol. 2013;50:148-52.

10. Cardoso DM, Campoli PM, Yokoi C, Ejima FH, Barreto PA, de Brito AM, et al. Initial experience in Brazil with endoscopic submucosal dissection for early gastric cancer using insulation-tipped knife: a safety and feasibility study. Gastric Cancer. 2008;11:226-32.

11. Neuhaus H. Endoscopic submucosal dissection in the upper gastrointestinal tract: presente and future view of Europe. Dig Endosc. 2009;21 (Suppl 1): 54-6.

12. Azmi AN, Khor CJL, Ho KY, Pittayanom R, Rerknimitr R, Ratanachu-ek, T, et al. Endoscopic submucosal dissection outcomes for gastroesophageal tumors in low volume units: A Multicenter Survey. Diagn Ther Endosc. 2016; 2016:5670564.

13. Cho KB, Jeon WJ, Kim JJ. Worldwide experiences of endoscopic submucosa dissection: not just Eastern acrobatics. World J Gastroenterol. 2011;17:2611-7.
14. Friedel D, Stavropoulos SN. Introduction of endoscopic submucosal dissection in the West. World J Gastrointest Endosc. 2018;10:225-38.

15. Farhat S, Chaussade S, Ponchon T, Coumaros D, Charachon A, Barrioz T, et al. Endoscopic submucosal dissection in a European setting. A Multi-Institutional report of a technique in development. Endoscopy. 2011;43:664-70.

16. Pagano N, Frazzoni L, LaPorta M, Fuccio L, Bazzoli F, Zagari RM. Endoscopic submucosal dissection for superficial premalignant and malignant epithelial neoplasms of digestive tract: a real-life experience in Italy. Eur Rev Med Pharm Sci. 2019;23:8254-9.

17. Barret M, Lepiliez V, Coumaros D, Chaussade S, Leblanc S, Ponchon T, et al. The expansion of submucosal dissection in France: a prospective Nationwide survey. United European Gastroenterol J. 2017;5:45-53.

18. Araujo-Martins M, Pimentel-Nunes P, Libanio D, Borges-Canha M, Dinis-Ribeiro $\mathrm{M}$. How is endoscopic submucosal dissection for gastrointestinal lesions being implemented? Results from an international survey. GE Port J Gastrenterol. 2020;27:1-17

19. Maselli R, Iacopini F, Azzolini F, Petruzziello L, Manno M, Luca LD, et al. Endoscopic submucosal dissection: Italian national survey on current practices, training and outcomes. Dig Liver Dis. 2020;52:64-71.

20. Choi IJ, Kim CG, Chang HJ, Kim SG, Kook CM, Bae JM. The learning curve for EMR with circumferential mucosal incision in treating intramucosal gastric neoplasm. Gastrointest Endosc. 2005;62:860-5.

21. Kakushima N, Fujishiro M, Kodashima S, Muraki Y, Tateishi A, Omata M. Learning curve for endoscopic submucosal dissection of gastric epithelial neoplasms. Endoscopy. 2006;38:991-5.

22. Gotoda T, Ho KY, Soetikno R, Kaltenbach T, Draganov PV. Gastric ESD: current status and future directions of devices and training. Gastrointest Endosc Clin North Am. 2014;24:213-33.

23. Herreros de Tejada A. ESD training: A challenging path to excellence. World $\mathbf{J}$ Gastrointest Endosc. 2014;6:112-20.

24. Draganov PV, Gotoda T, Chavalitdhamrong D, Wallace MB. Techniques of endoscopic submucosa dissection: application for the Western Endoscopist? Gantrointest Endosc. 2013;78:677-88.

25. Geraghty J, O’Toole P, Anderson J, Valori R, Sarka S. National survey to determine current practices, training and attitudes towards advanced polypectomy in the UK. Frontline Gastroenterology. 2015;6:85-93. 